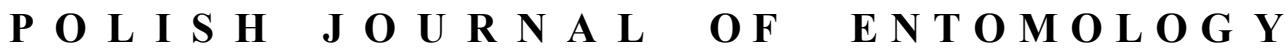

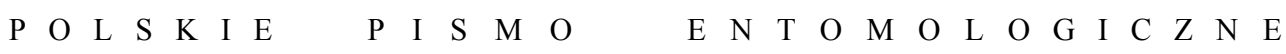

VOL. 82: 25-33

Gdańsk

31 March 2013

DOI: $10.2478 / \mathrm{v} 10200-012-0020-0$

\section{New faunistic and host records of Lepidoptera from Poland, with Stigmella naturnella (KLIMESCH, 1936) reported for the first time}

\author{
TOMASZ BARAN
}

Department of Invertebrate Zoology, University of Rzeszów, Zelwerowicza 4, 35-601 Rzeszów, Poland, e-mail: tbaran@univ.rzeszow.pl

\begin{abstract}
New records of eleven rare species of Lepidoptera are given from Poland. Stigmella naturnella (KLIMESCH, 1936) (Nepticulidae) has been recorded in Poland for the first time. Surprisingly, this nepticulid was found in an artificial ecosystem - a city park. The occurrence of Scrobipalpula tussilaginis (FREY, 1867) and Ephysteris inustella (ZELLER, 1847) in Poland has been confirmed after over a century. Salix caprea L. is given as the first reliable record of a host plant for the larva of Teleiodes flavimaculella, and Betula pubescens EHRH. is found to be a new host plant of Stigmella naturnella.
\end{abstract}

KEY WORDS: Lepidoptera, Microlepidoptera, new records, host plants, distribution, Poland.

\section{INTRODUCTION}

It is a well-known fact that in the case of Lepidoptera, especially micro-moths, the rearing of preimaginal stages is often the best way of recording many species that are local or difficult to catch as an imago. For the most part, this paper presents the results of the author's recent attempts to breed these moths. The rearing of some nepticulid larvae found on birch leaves in south-eastern Poland resulted in the discovery of a new moth for the Polish fauna, namely, Stigmella naturnella (KLIMESCH, 1936). The diagnostic features and general distribution of this species is briefly characterized.

Most of these records are based on reared imagines. The record of Eriocrania sangii (WOOD, 1891) is based on its distinctive larvae and that of Coleophora hydrolapathella HERING, 1921 on its larval cases and host plant. In this report, the only faunistic record based on adults collected in the field is that of Ephysteris inustella (ZELLER, 1847), one of the most locallyoccurring species of the Gelechiidae family in Poland. Two new host records are also given. 
The taxa belong to three superfamilies: Eriocranioidea, Nepticuloidea and Gelechioidea; all the specimens are deposited in the author's collection.

\section{SYSTEMATICS}

\section{Eriocrania sangii (WoOD, 1891) (Eriocraniidae)}

(Fig. 1)

\section{Material examined}

Gać ad Nowy Dwór Mazowiecki (DD 70, C Poland), 5 mines with larvae, 30 IV 2011 host plant: Betula pendula Rотн (leg., coll. T. Baran). The habitat was the sunny, birchlined edge of a meadow.

\section{Discussion}

This species is one of the most local eriocraniids in Poland. So far, it has been recorded at only three sites: Sołdany, Kraków and Dobranowice (RAZOWSKI 1975). The new record is based on the larval stage only. It is nonetheless reliable, as larvae of Eriocrania sangii can be fairly easily identified by their grey body colour (Fig. 1).

\section{Stigmella naturnella (KLIMESCH, 1936) (Nepticulidae)}

(Figs 2-3, 13-16)

\section{Material examined}

Rzeszów (EA 74, SE Poland), 1 male (Fig. 2), 1 female, ex larva, 22 VII 2011 - host plant: Betula pubescens EHRH. (leg., coll. T. Baran). The mines were collected in a small city park, mainly with Quercus rubra L., Larix decidua Mill., Pinus nigra ARNold, Acer pseudoplatanus L. and Betula pubescens EHRH.

\section{Discussion}

Stigmella naturnella is a new moth in the Polish fauna. In Central Europe, the species is rare and known from comparatively few localities. So far, it has been recorded only in northern Italy, Austria, Germany, Hungary, the Czech Republic and Slovakia (LAŠTŮVKA \& LAŠTU゚VKA 1997). Stigmella naturnella has also been reported from European and Far Eastern Russia, where it appears to be a more common leaf-miner (NIEUKERKEN et al. 2004).

In the Central European fauna, Stigmella naturnella is one of seven species of the genus Stigmella mining birch leaves. The mines of this nepticulid most resemble and are the most difficult to separate from those of Stigmella luteella (STAINTON, 1857), S. confusella (WoOD \& WALSINGHAM, 1894) and S. betulicola (STAINTON, 1856). Externally, the adult of Stigmella naturnella can also be difficult to identify because it appears very similar to S. betulicola, S. sakhalinella PUPLESIS, 1984 and S. luteella. Nevertheless, the combination of the following features may be helpful in the identification of this Betula miner: forewing dark, blackish brown, with obvious fascia reaching costa, apical cilia white, frontal tuft 
orange yellow, collar and comparatively large scapus uniformly whitish to creamy white (Fig. 2). Stigmella naturnella can be definitely separated from the others by examination of the genitalia, which are quite characteristic, especially those of the males. In the male genitalia, the presence of some small tooth-like, and two strong, almost straight thorn-like cornuti in the aedeagus, as well as the distinctive shape of the gnathos and the elongated processes by the aedeagus are the most obvious diagnostic features (Figs 13-14). In the female genitalia, the relatively large accessory sac, the long corpus bursae covered with distinct spines, and the shape of tergite 8 may be useful characters for identifying the species (Figs 15-16).

It is worth mentioning that Stigmella naturnella was found in a rather atypical biotope. This was an anthropogenic community (a small park) with just a few downy birches, located in the city centre close to the main roads of Rzeszów and the River Wisłok. Although quite a large number of Stigmella naturnella mines (both empty and tenanted) were found, only two adults emerged in captivity. This finding is intriguing as this moth has so far been regarded as a rather thermophilic species associated with warm, or even xerothermic and steppe habitats. Moreover, only Betula pendula ROTH has hitherto been mentioned as a host plant of the species (LAŠTU゚VKA \& LAŠTU゚VKA 1997). Betula pubescens is thus a new host record for Stigmella naturnella.

\section{Elachista exactella (HERRICH-SCHÄFFER, 1855) (Elachistidae)}

(Fig. 4)

\section{Material examined}

Nisko (EA 89, SE Poland), 7 males (Fig. 4), 3 females, ex larva, 30 VI, 1 male, 4 females, ex larva, 1 VII, 5 males, 3 females, ex larva, 2 VII, 1 male, 8 females, ex larva, 3 VII, 1 female, ex larva, 4 VII 2009, 1 female, ex larva, 5 III 2012 - host plant: Deschampsia flexuosa (L.) TRIN. (leg., coll. T. Baran). The mines were collected in a pine forest with an admixture of some young Abies alba MILLER.

\section{Discussion}

Elachista exactella is a rare taxon in Poland. It has hitherto been known from just a few scattered, mainly historical records, some of which may be unreliable, as the species has frequently been confused with other elachistids. In recent decades, it has been found only in the Tatra Mts. (BusZKO 2000).

\section{Agonopterix senecionis (NICKERL, 1864) (Depressariidae)}

(Fig. 5)

\section{Material examined}

Dąbrówka Starzeńska ad Dynów (EA 91, SE Poland), 1 male, ex larva, 20 VII, 1 male, 1 female, ex larva, 21 VII, 1 female (Fig. 5), ex larva, 22 VII, 2 females, ex larva, 25 VII, 
1 male, 1 female, ex larva, 26 VII, 1 male, ex larva, 27 VII 2011 - host plant: Senecio ovatus (P. GAERTN., B. MEY \& SCHERB.) Willd. (leg., coll. T. Baran). The mining larvae were found in shady localities in the Carpathian beech forest.
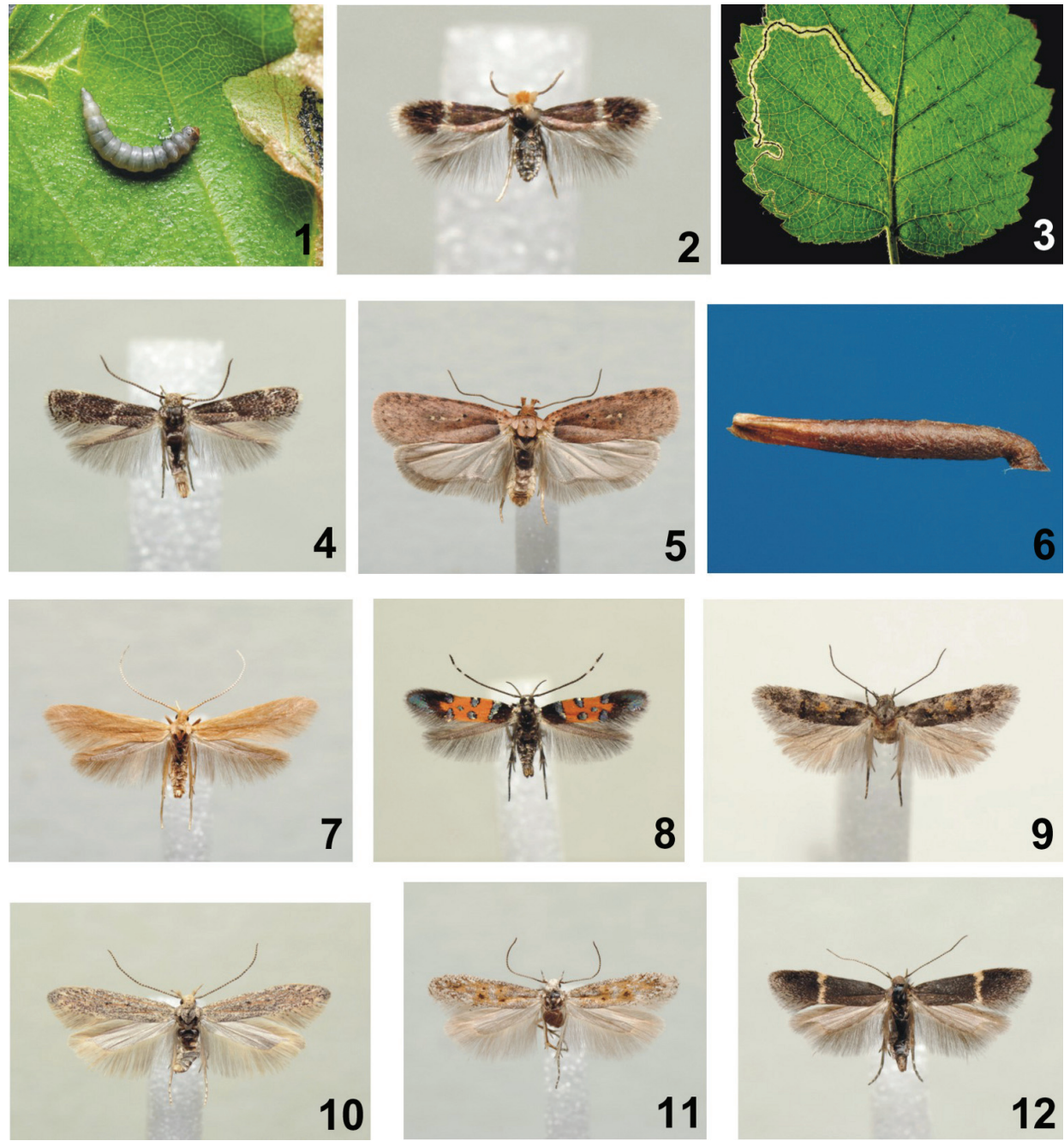

Figs 1-12. 1 - larva of Eriocrania sangii, 2 - adult male of Stigmella naturnella, 3 - leaf mine of Stigmella naturnella on Betula pubescens, 4 - adult male of Elachista exactella, 5 - adult female of Agonopterix senecionis, 6 - larval case of Coleophora hydrolapathella, 7 - adult male of Coleophora ochripennella, 8 - adult male of Stagmatophora heydeniella, 9 - adult female of Teleiodes flavimaculella, 10 - adult male of Scrobipalpula tussilaginis, 11 - adult male of Ephysteris inustella, 12 - adult male of Syncopacma ochrofasciella. 


\section{Discussion}

For a very long time, this extremely rare species was known exclusively from the Chełmiec Mt. (the Wałbrzyskie Mts.) (WocKE 1874). Recently, Agonopterix senecionis was rediscovered after an interval of more than a hundred years: it was recorded at two localities in the Opawskie Mts. (BLAIK 2007). The new record from south-eastern Poland is the first one outside the Sudeten Mts.
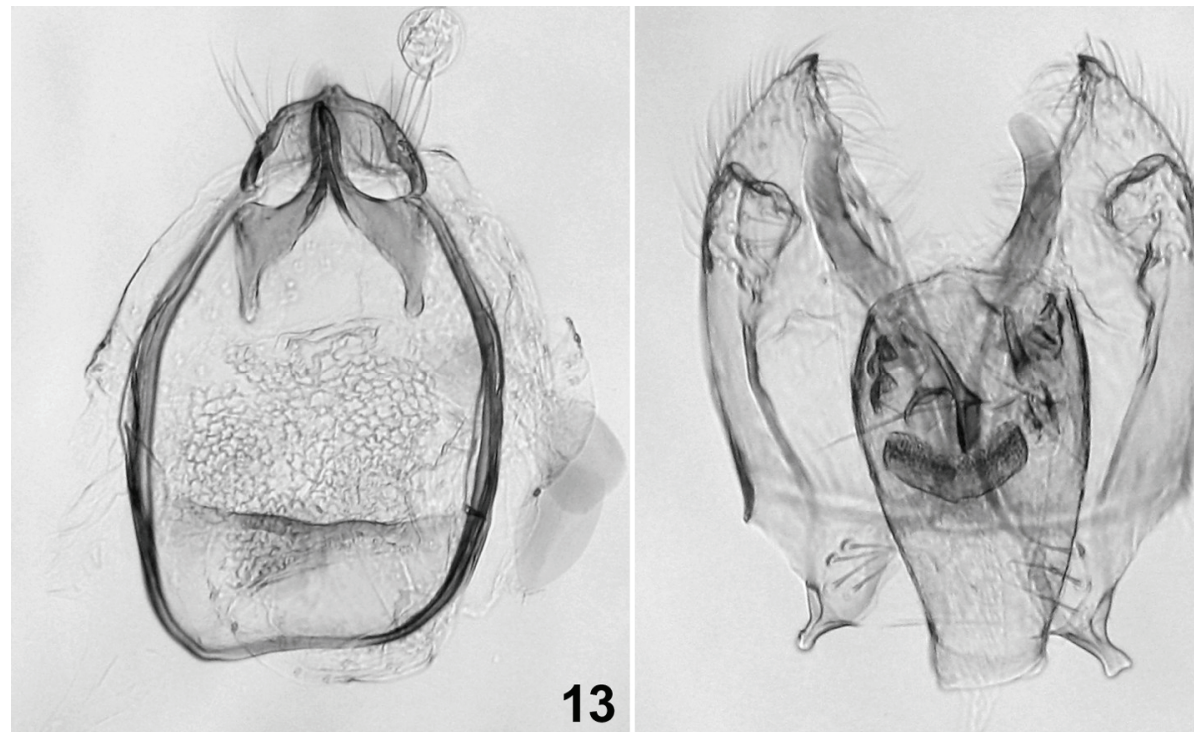

Figs 13-14. Male genitalia of Stigmella naturnella: 13 - vinculum-tegumen-uncus-gnathos complex, 14 - valvae and aedeagus.

\section{Coleophora hydrolapathella HERING, 1921 (Coleophoridae)}

(Fig. 6)

\section{Material examined}

Gać ad Nowy Dwór Mazowiecki (DD 70, C Poland), 10 larval cases, 30 IV 2011 - host plant: Rumex hydrolapathum HUDSON (leg., coll. T. Baran). The habitat was an open, wet meadow with a small stream. The larval cases were attached to dry stems of the food plant.

Breeding of the material from Gać was unsuccessful. However, the determination of the species is certain as Coleophora hydrolapathella is the only coleophorid species in Europe whose larvae feed on Rumex hydrolapathum in slender, deep brownish tubular and trivalved cases (Fig. 6).

\section{Discussion}

Coleophora hydrolapathella was only recently recorded in Poland for the first time (FUGLEWICZ \& FUGLEWICZ 2002): it was found at three localities in the westernmost part of 
the country: Nowogród Bobrzański, Cieszów and Buczek (FUGLEwICZ \& FUGLEWICZ op. cit.). The present record suggests the more widespread occurrence of the species in Poland.

\section{Coleophora ochripennella ZELLER, 1849 (Coleophoridae)}

(Fig. 7)

\section{Material examined}

Dąbrówka Starzeńska ad Dynów (EA 91, SE Poland), 1 male, ex larva, 19 V, 3 males, 1 female, ex larva, 21 V, 1 male (Fig. 7), ex larva, 22 V 2011 - host plant: Stachys sylvatica L. (leg., coll. T. Baran). The larval cases were collected predominantly in shady localities in the Carpathian beech forest.

\section{Discussion}

In Poland, Coleophora ochripennella was previously reported from the vicinity of Gdańsk (SCHILLE 1930), Głogówek, Stemplew (RAZOWSKI 1990), and the Lubuskie region (RYNARZEWSKI 2000). The species is local but can be abundant where it occurs. It is comparatively easy to find, especially in the larval stage.

\section{Stagmatophora heydeniella (FISCHER VON RöSLERSTAMM, 1838) (Cosmopterigidae)}

(Fig. 8)

\section{Material examined}

Tyczyn (EA 73, SE Poland), 1 male (Fig. 8), 1 female, ex larva, 13 VIII, 1 male, ex larva, 15 VIII, 1 male, 1 female, ex larva, 18 VIII, 1 male, ex larva, 19 VIII 2011, 1 male, ex larva, 11 III, 3 males, 2 females, ex larva, 12 III, 1 male, 1 female, ex larva, 13 III 2012 - host plant: Stachys officinalis (L.) TREV. (leg., coll. T. Baran). The habitat was a somewhat shady spot at the edge of a mixed forest.

\section{Discussion}

This very local species was previously known only from Oleśnica near Wrocław (Wocke 1874), the Wieprzec Reserve (BUSZKo 1992) and the Brzeźno Reserve (MAZURKIEWICZ \& PAŁKA 2005).

\section{Teleiodes flavimaculella (HERRICH-SCHÄFFER, 1854) (Gelechiidae)}

(Fig. 9)

\section{Material examined}

Dąbrówka Starzeńska ad Dynów (EA 91, SE Poland), 1 female (Fig. 9), ex larva, 17 III 2012 - host plant: Salix caprea L. (leg., coll. T. Baran). The habitat was a moist spot at the edge of the Carpathian beech forest, with just a few young trees of Salix caprea. 


\section{Discussion}

So far, this local gelechiid moth has been found in only three localities in central and north-eastern Poland: the Las Piwnicki Reserve (BUSZKO 1991), the Borecka forest (BuszKo et al. 2000, leg. J. Buszko), and Białowieża (BARAN et al. 2001).

Knowledge of the distribution and biology of Teleiodes flavimaculella is very scanty, as it is often confused with Teleiodes luculella (HÜBNER, 1813). In fact, there is no reliable information on the food plant preferences of the species. Salix caprea is therefore treated here as the first trustworthy host plant record for Teleiodes flavimaculella.

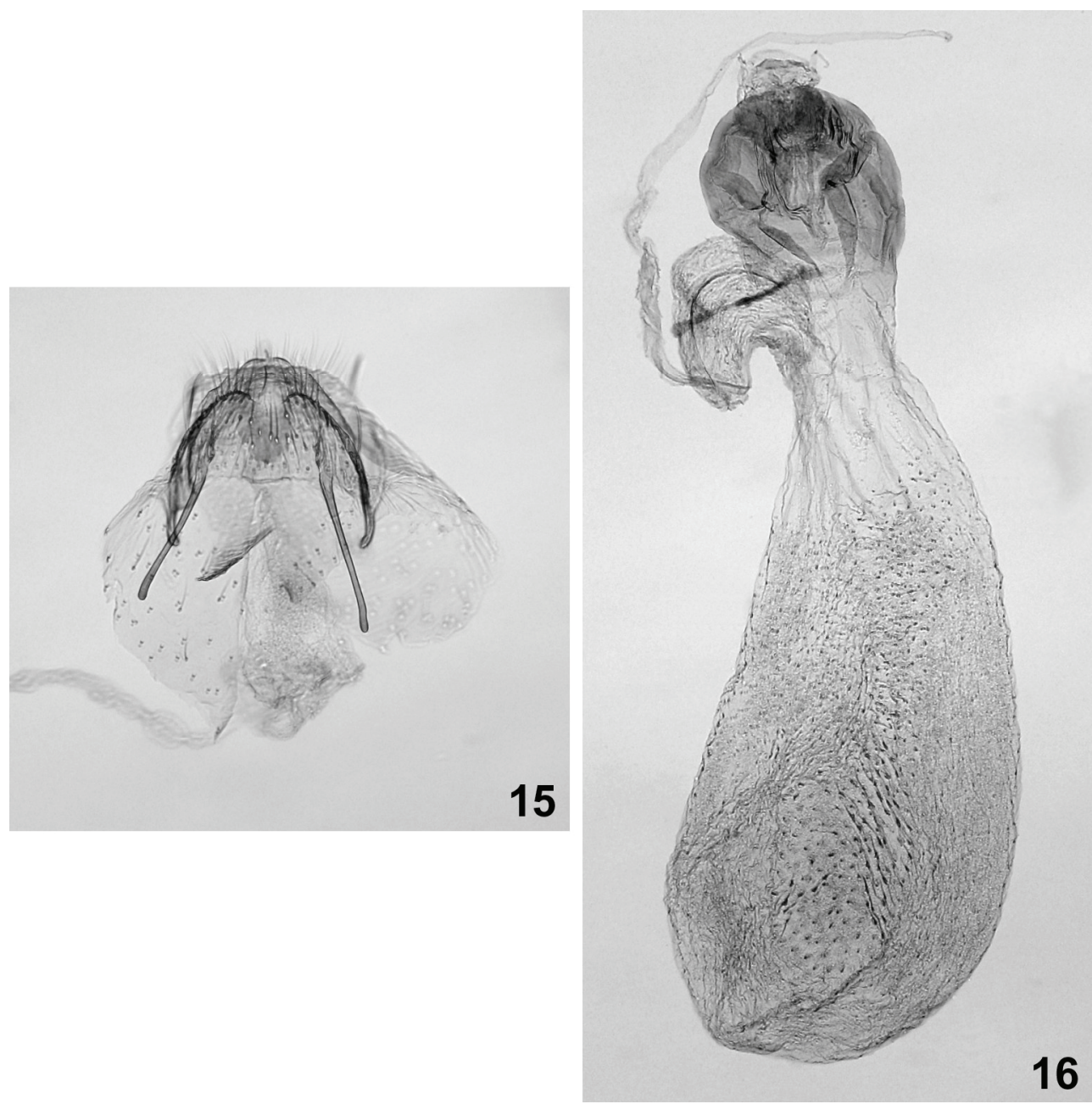

Figs 15-16. Female genitalia of Stigmella naturnella: 15 - terminal segments, 16 - corpus bursae and accessory sac. 


\section{Scrobipalpula tussilaginis (FREY, 1867) (Gelechiidae)}

(Fig. 10)

\section{Material examined}

Gacki ad Pińczów (DA 79, S Poland), 1 male, ex larva, 8 III, 2 males, ex larva, 10 III, 1 female, ex larva, 12 III, 1 female, ex larva, 14 III, 1 male, ex larva, 19 III 2012 - host plant: Tussilago farfara L. (leg., coll. T. Baran); Dąbrówka Starzeńska ad Dynów (EA 91, SE Poland), 1 male (Fig. 10), 1 female, ex larva, 9 III 2012 - host plant: Tussilago farfara L. (leg., coll. T. Baran). The tenanted mines were collected in sunny open meadows, as well as in warm sites at edges of the Carpathian beech forest.

\section{Discussion}

This very rare species was previously known in the country from just two $19^{\text {th }}$ century records, namely, from Wrocław (WOCKE 1874) and the vicinity of Szczecin (BÜTTNER 1880). The present record is reconfirmation of the occurrence of Scrobipalpula tussilaginis in Poland.

\section{Ephysteris inustella (ZELLER, 1847) (Gelechiidae)}

(Fig. 11)

\section{Material examined}

Męćmierz ad Kazimierz Dolny (EB 68, SE Poland), 1 female, 2 VII, 2 males, 3 VII, 1 male (Fig. 11), 1 female, 6 VII 2008 (leg., coll. T. Baran). The habitat was a psammophilous, xerothermic grassland near a small hill with calcareous soil. The moths were collected by sweeping the low vegetation with a net on warm days.

\section{Discussion}

This extremely local and stenotopic micro-moth was previously known only from Głogów (WOCKE 1874). This new, second record is reconfirmation of the occurrence of Ephysteris inustella in Poland.

\section{Syncopacma ochrofasciella (ToLL, 1936) (Gelechiidae)}

(Fig. 12)

\section{Material examined}

Tyczyn (EA 73, SE Poland), 1 male, 2 females, ex larva, 12 VII 2010 - host plant: Astragalus glycyphyllos L. (leg., coll. T. Baran); Kąty II ad Zamość (FB 41, SE Poland), 1 male, ex larva, 15 VII, 1 male (Fig. 12), ex larva, 17 VII 2010 - host plant: Astragalus glycyphyllos L. (leg., coll. T. Baran). The habitats were the sunny edges of a mixed forest and open, xerothermic grassland.

\section{Discussion}

This local species was discovered in Poland not very long ago. It was found for the first 
time in the Zbocza Płutowskie Reserve (ELSNER et al. 1999). Syncopacma ochrofasciella has also been recorded from Biedrusko near Poznań (WALCZAK 2011).

\section{REFERENCES}

Baran T., Bengtsson B.A., Karsholt O. 2001. New for the Polish fauna and rare Microlepidoptera (Lepidoptera) from the Białowieża forest. Polskie Pismo Entomologiczne 70: 201-210.

BLAIK T. 2007. Contribution to the knowledge of the Microlepidoptera (Gelechioidea: Ethmiidae, Depressariidae, Chimabachidae, Oecophoridae) of south-western Poland - new data from Opole Province. Opole Scientific Society Nature Journal 40: 35-48. [in Polish].

Buszko J. 1991. Motyle (Lepidoptera) rezerwatu Las Piwnicki. Parki Narodowe i Rezerwaty Przyrody 10: 5-60.

Buszko J. 1992. New records of Cosmopterix lienigiella LiEN. et Zell. and Stagmatophora heydeniella (F. v. R.) (Lepidoptera, Cosmopterigidae) in Poland. Wiadomości Entomologiczne 11: 63. [In Polish].

Buszko J. 2000. Elachistidae. [In:] Buszko J. \& NowAcki J. (eds). The Lepidoptera of Poland. A distributional checklist. Polish Entomological Monographs 1: 33-34.

BuszKo J., KARShOlt O., RynARZEWSKi T. 2000. Gelechiidae. [In:] Buszko J. \& NowACKI J. (eds). The Lepidoptera of Poland. A distributional checklist. Polish Entomological Monographs 1: 33-34.

BÜTTNER F.O. 1880. Die Pommerschen, insbesondere die Stettiner Microlepidopteren. Stettiner Entomologische Zeitung 41: 383-473.

Elsner G., Huemer P., ToKÁr Z. 1999. Die Palpenmotten (Lepidoptera, Gelechiidae) Mitteleuropas. Bestimmung, Verbreitung, Flugstandort, Lebensweise der Raupen. Slamka, Bratislava, 208 pp.

Fuglewicz E., Fuglewicz S. 2002. Coleophora hydrolapathella M. Hering, 1921 (Lepidoptera: Coleophoridae) - a moth new to the fauna of Poland. Wiadomości Entomologiczne 21: 163-166. [In Polish].

LAŠTU゚VKA A., LAŠTU゚VKA Z. 1997. Die Nepticulidae Mitteleuropas. Ein illustrierter Begleiter (Lepidoptera). Konvoj Verlag, Brno, 230 pp.

MaZURKIEWICZ A., PAŁKA K. 2005. New localities of rare species of Cosmopterigidae (Lepidoptera) in south-eastern Poland. Wiadomości Entomologiczne 24: 191-192. [In Polish].

Nieukerken E.J. van, Zolotuhin V.V., Mistchenko A. 2004. Nepticulidae from the Volga and Ural region. Nota Lepidopterologica 27: 125-157.

RAzowski J. 1975. Motyle (Lepidoptera) Polski. Część II - Homoneura. Monografie Fauny Polski 5: $1-96$.

Razowski J. 1990. Motyle (Lepidoptera) Polski. Część XVI - Coleophoridae. Monografie Fauny Polski 18: 1-270.

Rynarzewski T. 2000. Coleophoridae. [In:] Buszko J. \& NowACKi J. (eds). The Lepidoptera of Poland. A distributional checklist. Polish Entomological Monographs 1: 38-42.

SChILle F. 1930. Fauna Motyli Polski. II. Prace Monograficzne Komisji Fizjograficznej 7: 1-358.

WALCZAK U. 2011. Leaf-mining moths (Lepidoptera) of the Biedrusko military area in western Poland. Fragmenta Faunistica 54: 113-136.

Wocke M.F. 1874. Verzeichnis der Falter Schlesiens. II. Microlepidoptera. Zeitschrift für Entomologie, N. F. 4: 1-107.

Received: December 27, 2012

Accepted: February 22, 2013 